\title{
ASSISTÊNCIA SOCIAL E RESPONSABILIDADE SOCIAL DA IGREJA
}

SOCIAL ASSISTANCE AND SOCIAL RESPONSIBILITY OF THE CHURCH

\section{Maria Cristina de Assis ${ }^{10}$ Maria Elisabete Ribeiro Clemente ${ }^{11}$}

10 Doutora em Linguística pela Universidade Federal de Pernambuco, Mestre em Letras pela Universidade Federal da Paraíba, Especialista em Teologia e Transformação Integral pela FICV. Email: xtinassis@gmail.com

11 Mestre em Sociologia Rural pela Universidade Federal da Paraiba, Especialista em Planejamento e Gestão em Defesa Civil e em Formação Urbana do Nordeste pela UFPB. Especializanda em Teologia e Transformação Integral pela FICV. Email: elisabeteribeiroclemente@gmail.com 


\section{RESUMO}

O presente trabalho se propõe a apresentar um breve panorama histórico sobre como o chamado à misericórdia feito por Jesus Cristo vem sendo entendido pelos cristãos ao longo dos séculos. Trata-se de uma questão que vem ocasionando intensos debates entre cristãos, em decorrência de entendimentos diferentes em relação ao que é prioritário na missão da igreja de Cristo. A pesquisa revela três entendimentos principais: os que defendem a prioridade da evangelização, os que concebem que a evangelização deve ser acompanhada de responsabilidade social e ainda os que consideram a evangelização e a responsabilidade social são complementares, sem que haja prioridade entre elas. Discute-se o conceito de responsabilidade social da Igreja, por meio de uma revisão bibliográfica, de cunho histórico.

\section{PALAVRAS-CHAVE}

Cristianismo. Igreja. Missão. Responsabilidade Social.

\section{ABSTRACT}

This paper presents a brief historical overview of how the call to mercy made by Jesus Christ has been understood by Christians over the centuries. This is an issue that has been causing intense debate among Christians, due to different understandings regarding what is a priority in the mission of Christ's church. The research reveals three main understandings: those who advocate the priority of evangelization, those who believe that evangelization must be accompanied by social responsibility, and those who consider evangelization and social responsibility to be complementary, with no priority between them. The concept of the Church's social responsibility is discussed by means of a bibliographical revision of a historical nature

\section{KEYWORDS}

Christianity. Church. Mission. Social responsability. 


\section{INTRODUÇÃO}

Uma das questões predominantes nos debates entre cristãos não apenas na atualidade, mas, no decorrer dos séculos, refere-se ao papel da igreja frente às demandas sociais. Muitos cristãos questionam qual a responsabilidade da igreja nesse cenário de pobreza, doença, abandono em que vivem crianças, velhos, homens e mulheres, entendendo que a missão da igreja deve ser vista em sua relação com Deus e com Cristo. Nesse sentido, indaga-se de que modo as ações da Igreja no âmbito social concebem o usuário da assistência social e de que modo os cristãos praticaram a caridade ao longo dos séculos. Este artigo aborda o conceito de responsabilidade social, enquanto integrado à missão da igreja, partindo da narrativa bíblica no Antigo e no Novo Testamento e na Igreja cristã no período Medieval, enfatizando as ações da Igreja Católica e da Reforma Protestante, tomando por base o pensamento de Calvino e de outros teólogos reformados.

Esse tema se justifica, em primeiro lugar, por se tratar de um mandamento do próprio Cristo e, em segundo, por ser um debate bastante recorrente no cristianismo. Por outro lado, dados recentes de pesquisas mostram o número crescente de necessitados no Brasil. São grupos heterogêneos de pessoas: desempregados ou subempregados, trabalhadores de baixarenda, sem-teto, enfermos, estrangeiros, idosos, encarcerados, outras etnias, enfim, seres humanos que passam por diferentes tipos de necessidades. Timothy Keller (2016, p.31), ao analisar a situação de empobrecimento nos EUA durante as décadas de 70 a 90 do século passado, afirma que a igreja de Jesus Cristo precisa encarar sua responsabilidade pelos semelhantes que estão morrendo à beira da estrada. Diante desse cenário, opiniões divergem sobre o papel da igreja, resultando em ações distintas entre as mais diversas congregações cristãs.

Antes de abordar a responsabilidade social da igreja, é importante ressaltar que não se trata da filantropia ou da ação social corporativa, praticada modernamente por empresas. Do mesmo modo, não se refere ao conceito de justiça social usado em termos políticos. Nesse sentido, Timothy Keller (2013, p.69-70) ressalta que, no famoso Sermão do Monte, Jesus uniu, em um único bordado, a moralidade individual e a justiça social, o que, conforme o autor, não parece ter sido reconhecido pelos leitores bíblicos. Ainda conforme Keller, no mundo ocidental _ e ele exemplifica com 
os Estados Unidos _ igrejas mais conservadoras ou mais liberais, e partidos políticos de direita ou de esquerda construíram suas plataformas políticas sobre uma dessas prescrições, em detrimento das outras:

O partido da direita enfatiza a importância da moralidade pessoal, particularmente a importância dos padrões morais sexuais e da dedicação ao trabalho e considera exageradas as acusações de racismo e injustiça social que o partido de esquerda lhe faz. Por outro lado, o partido de esquerda dá ênfase à justiça social e considera hipócrita e psicologicamente nociva a ênfase que os políticos de direita atribuem às virtudes morais. Naturalmente, um partido vê o outro como presunçoso e farisaico. (KELLER, 2013, p.70)

A esquerda acredita que os males sociais seriam resolvidos por uma grande reforma governamental, enquanto a direita defende que a resolução desses males depende de grandes negócios e crescimento econômico. No tocante às igrejas, conforme o autor, as igrejas americanas tendem a ser mais controladas pela cultura política em que se inserem do que pelo ensino de Jesus e dos profetas e a concentrar-se em grupos distintos de pecados. Keller (2016; p. 32) cita o alerta de Francis Schaffer, para que os cristãos não se aliem às ideologias, enquanto realizam a tarefa de cuidar do semelhante, em necessidade:

Se houver injustiça social, digam que há injustiça social. Se precisamos de ordem, digam que precisamos de ordem [...] Mas não se alinhem como se estivessem em um desses campos Você não é aliado de nenhum deles. A igreja de Cristo é diferente dos dois - totalmente diferente. (SHAFFER, apud Keller, 2016; p. 32)

Nesta pesquisa, utilizam-se os termos responsabilidade social, assistência social e justiça social como uma ação voltada para atender as necessidades prementes da população desassistida, entendendo que todos os homens foram criados à imagem e semelhança de Deus e, portanto, necessitam de serem restaurados em sua dignidade humana. 
Como metodologia, fez-se uma pesquisa bibliográfica baseada em autores como Blainey (2012), Carvalho (2009), Lopes (2011), Goheen; Bartholomew (2004; 2016); Gruden (1999), e artigos científicos publicados em revistas cristãs na internet. Adotase a perspectiva cronológica, considerando a assistência aos pobres na perspectiva judaico-cristã, a partir do Antigo Testamento até o momento atual.

Para tratar da questão, este trabalho estrutura-se nos tópicos seguintes: inicialmente, apresenta-se o conceito de responsabilidade social adotado na pesquisa; a seguir, aborda-se a perspectiva bíblica de assistência aos necessitados, observando como ocorria essa assistência tanto no Antigo quanto no Novo Testamento. Finalmente, aponta-se como a igreja cristã - Católica e Reformada - vem lidando com a questão, ao longo dos séculos.

Diante do exposto, é, portanto, objetivo geral deste trabalho, apresentar um breve panorama histórico sobre a responsabilidade social da Igreja, por meio de uma revisão bibliográfica.

\section{SOBRE O CONCEITO DE RESPONSABILIDADE SOCIAL: QUAL A MISSÃO DA IGREJA?}

Para entender a missão da igreja, conforme Gruden (1999, p.726) é essencial relacionar essa missão a ministérios ligados, primeiramente a Deus, aos cristãos e ao mundo. O propósito da igreja em relação a Deus consiste em adorá-lo; em relação aos cristãos, edificá-los, levando-os à maturidade na fé; e em relação ao mundo, consiste em evangelização e misericórdia. No tocante à relação com o mundo, ainda segundo o teólogo, a evangelização é considerada por muitos cristãos como prioritária, embora o cuidado com os pobres e necessitados, em nome do Senhor, seja parte integrante do ministério de misericórdia.

O conceito de responsabilidade social - aqui utilizado ora como justiça social, ora como assistência social, associados à misericórdia, caridade - está relacionado a princípios bíblicos, concebido como uma forma de suprir as necessidades básicas das pessoas, proporcionando condições de vida mais dignas, alívio do sofrimento humano e atenuar ou eliminar os males sociais que afligem indivíduos, famílias ou comunidades. Não deve ser entendido como simples assistencialismo, mas como partes 
essenciais da missão da Igreja no mundo, a fim de que o nome de Deus seja glorificado.

O pensamento bíblico sobre a ajuda aos pobres está relacionado à percepção que se tem de Deus, ou seja, um Deus presente, que ama o homem e cuida dele, mesmo que esse homem não mereça.

Em princípio, a maioria das referências bíblicas refere-se aos pobres dentro da comunidade da aliança, na nação de Israel, que recebeu a ordem de desenvolver uma cultura de justiça social para os pobres e vulneráveis porque era assim que a nação revelaria a glória e o caráter de Deus ao mundo (KELLER, 2013, p. 29) Porém, inúmeras outras passagens estendem a prática da caridade à humanidade, e Deus é apresentado como o defensor dos grupos vulneráveis.

Se houver algum israelita pobre em qualquer das cidades da terra que o Senhor, o seu Deus, Ihe está dando, não endureçam o coração, nem fechem a mão para com o seu irmão pobre. Ao contrário, tenham mão aberta e emprestem-Ihe liberalmente o que ele precisar. Cuidado! Que nenhum de vocês alimente este pensamento ímpio: "O sétimo ano, o ano do cancelamento das dívidas, está se aproximando, e não quero ajudar o meu irmão pobre". Ele poderá apelar para o Senhor contra você, e você será culpado pelo pecado. Dê-lhe generosamente, e sem relutância no coração; pois, por isso, o Senhor, o seu Deus, o abençoará em todo o seu trabalho e em tudo o que você fizer. Sempre haverá pobres na terra. Portanto, eu lhe ordeno que abra o coração para o seu irmão israelita, tanto para o pobre como para o necessitado de sua terra. (Deuteronômio 15:7-11)

O que faz justiça aos oprimidos, o que dá pão aos famintos. O Senhor solta os encarcerados. $O$ Senhor abre os olhos aos cegos; o Senhor levanta os abatidos; Senhor ama os justos; O Senhor guarda os estrangeiros; sustém o órfão e a viúva, mas transtorna o caminho dos ímpios. (Salmos 146:7-9) 
Por outro lado, o termo pobre não deve ser entendido exclusivamente relacionado a pessoas carentes, de uma perspectiva econômica, mas também a pessoas desprovidas de posses, aos excluídos, aos que eram forçados a depender de Deus. Nesse sentido, Cunha; Wood (2019, p. 40-9) apresentam inúmeras palavras do hebraico e do grego que podem ser traduzidas em português pelo "pobre", revelando circunstâncias diferentes e possibilitando estratégias variadas de socorro: pobreza causada por aflição e opressão (ani), necessitado, dependente (ebion), pessoas empobrecidas por espoliação (rash), deficientes (machsor), pessoas frágeis, fracas (dal) e famintos (raeb), infeliz ou deprimido (chelkar), mendigos, pessoas totalmente dependentes dos outros (ptokos).

Embora a maioria das igrejas evangélicas atuais não se negue a socorrer necessitados e feridos, ainda há alguns cristãos que entendem o trabalho de assistência social como atividade secundária, ou que a igreja se desvia da sua missão de evangelizar, ao se engajar no serviço social, socorrendo os pobres. No entanto, teólogos como Keller (2016; p. 41) consideram a assistência ao necessitado parte integrante da missão. Para o autor, "A misericórdia diante de todo tipo de necessidade humana é uma marca tão essencial do cristão que pode ser usada como teste da fé verdadeira." Por outro lado, as Escrituras ressaltam que não é opcional para a igreja minorar o sofrimento humano, pelo contrário, é seguir o Cristo, agindo conforme o Mestre

[...] como Deus ungiu a Jesus de Nazaré com o Espírito Santo e poder, e como ele andou por toda parte fazendo o bem e curando todos os oprimidos pelo diabo, porque Deus estava com ele. (Atos 10:38)

A religião que Deus, o nosso Pai aceita como pura e imaculada é esta: cuidar dos órfãos e das viúvas em suas dificuldades e não se deixar corromper pelo mundo. (Tiago 1:27)

O próprio Jesus, ao apresentar sua missão, reivindica para si o cumprimento da profecia feita por Isaías (61:1):

O Espírito do Senhor está sobre mim, porque ele me ungiu para pregar boas novas aos pobres. Ele 
me enviou para proclamar liberdade aos presos e recuperação da vista aos cegos, para libertar os oprimidos e proclamar o ano da graça do Senhor. (Lucas 4:18,19)

De acordo com Keller, (2016; p. 41), Jesus Cristo, ao se referir à parábola do Bom Samaritano, usa a obra de misericórdia para mostrar a essência da justiça de Deus exige em nossos relacionamentos. Já no Evangelho de Mateus, Jesus revela o julgamento da humanidade que fará no dia do Juízo e, nesse julgamento, o amor e o cuidado com o semelhante são essenciais:

Quando o Filho do homem vier em sua glória, com todos os anjos, assentar-se-á em seu trono na glória celestial. Todas as nações serão reunidas diante dele, e ele separará umas das outras como o pastor separa as ovelhas dos bodes. E colocará as ovelhas à sua direita e os bodes à sua esquerda. "Então o Rei dirá aos que estiverem à sua direita: Venham, benditos de meu Pai! Recebam como herança o Reino que Ihes foi preparado desde a criação do mundo. Pois eu tive fome, e vocês me deram de comer; tive sede, e vocês me deram de beber; fui estrangeiro, e vocês me acolheram; necessitei de roupas, e vocês me vestiram; estive enfermo, e vocês cuidaram de mim; estive preso, e vocês me visitaram'. (Mateus 25:31-36)

Em seu ministério, Cristo privilegiou os pobres, compadecendo-se deles. Por isso, ao divulgar as boas-novas do reino de Deus e ao testemunhar sobre o evangelho, a Igreja Cristã deve compadecer-se dos marginalizados, em sua busca na promoção da justiça social e da transformação das estruturas sociais e culturais (GOHEEN; BARTHOLOMEW, 2016, p. 209).

\section{O CUIDADO COM OS POBRES NO ANTIGO E NO NOVO TESTAMENTO}

Segundo a Bíblia, no princípio, Deus criou o céu e a terra - e assim tem início a perfeita e boa Criação - e designou o homem, feito à Sua imagem e semelhança, como para sujeitá-la e dominá- 
la (Gn1:28). No entanto, o homem rebelou-se contra Deus. Com isso, não apenas foi quebrado o relacionamento humano com o Criador, mas toda a Criação foi contaminada pelo pecado (Gn 1:1318). Além disso, o pecado destruiu tanto a percepção que homem tinha de si mesmo quanto a percepção de pertencer uns aos outros (BARTHOLOMEW; GOHEEN, 2004, p. 52). Porém Deus não desistiu dos seres humanos: cobriu Adão e Eva com pele e animais. Esse ato pode revelar tanto o perdão dos nossos pecados, em Cristo, quanto a proteção e o próprio cuidado do Criador com o necessitado (Gn 1.21). Inicia-se a missão de redimir a Criação e, em Jesus Cristo, foram criadas as condições para a restauração tanto da Criação quanto da humanidade caída, que sofrem as consequências da Queda. Para isso, escolhe o povo judeu, a fim de que seja canal de bênção para os outros povos; envia o seu Filho Jesus Cristo com a missão de inaugurar o seu Reino na terra e, por fim, por meio da obra do Espírito Santo, comissiona a igreja, o corpo de Cristo, para integrar-se a esse propósito de restauração, que se completará com o retorno de Cristo (BARTHOLOMEW; GOHEEN, 2004).

No Antigo Testamento, várias passagens, seja nos relatos, exortações, leis ou nas ordenanças, revelam o cuidado de Deus para com os necessitados, sejam eles pobres, estrangeiros, órfãos ou viúvas. Na sociedade de Israel, medidas econômicas e sociais, fundamentadas no caráter de Deus, garantiam a proteção e o bemestar dos desamparados. Entre elas, citam-se o ano sabático, conforme em Levítico:

Então disse o Senhor a Moisés no monte Sinai: "Diga o seguinte aos israelitas: Quando vocês entrarem na terra que Ihes dou, a própria terra guardará um sábado para o Senhor. Durante seis anos semeiem as suas lavouras, aparem as suas vinhas e façam a colheita de suas plantações. Mas no sétimo ano a terra terá um sábado de descanso, um sábado dedicado ao Senhor. Não semeiem as suas lavouras, nem aparem as suas vinhas. Não colham o que crescer por si, nem colham as uvas das suas vinhas que não serão podadas. A terra terá um ano de descanso. Vocês se sustentarão do que a terra produzir no ano de descanso, você, o seu escravo, a sua escrava, o trabalhador contratado 
e o residente temporário que vive entre vocês, bem como os seus rebanhos e os animais selvagens de sua terra. Tudo o que a terra produzir poderá ser comido. "Contem sete semanas de anos, sete vezes sete anos; essas sete semanas de anos totalizam quarenta e nove anos. Então façam soar a trombeta no décimo dia do sétimo mês; no Dia da Expiação façam soar a trombeta por toda a terra de vocês. Consagrem o quinquagésimo ano e proclamem libertação por toda a terra a todos os seus moradores. Este Ihes será um ano de jubileu, quando cada um de vocês voltará para a propriedade da sua família e para o seu próprio clã. O quinquagésimo ano lhes será jubileu; não semeiem e não ceifem o que cresce por si mesmo nem colham das vinhas não podadas. É jubileu, e lhes será santo; comam apenas o que a terra produzir. "Nesse ano do jubileu cada um de vocês voltará para a sua propriedade. "Se vocês venderem alguma propriedade ao seu próximo ou se comprarem alguma propriedade dele, não explore o seu irmão. O que comprarem do seu próximo será avaliado com base no número de anos desde o Jubileu. E fará a venda com base no número de anos que restam de colheitas. Quando os anos forem muitos, vocês deverão aumentar o preço, mas quando forem poucos, deverão diminuir o preço, pois o que ele está lhes vendendo é o número de colheitas. Não explorem um ao outro, mas temam ao Deus de vocês. Eu sou o Senhor, o Deus de vocês. (Levítico 25:1-17)

No Antigo Testamento, a lei do jubileu revela o cuidado de Deus com seu povo, amenizando a pobreza. Relacionava-se à libertação dos escravos e a devolução das terras aos pobres e tinha o objetivo de manter livres os israelitas e na porção de terra específica que Deus Ihes dera:

Também contarás sete semanas de anos, sete vezes sete anos; de maneira que os dias das sete 
semanas de anos te serão quarenta e nove anos. Então no mês sétimo, aos dez do mês, farás passar a trombeta do jubileu; no dia da expiação fareis passar a trombeta por toda a vossa terra, E santificareis o ano quinquagésimo, e apregoareis liberdade na terra a todos os seus moradores; ano de jubileu vos será, e tornareis, cada um à sua possessão, e cada um à sua família. O ano quinquagésimo vos será jubileu; não semeareis nem colhereis o que nele nascer de si mesmo, nem nele vindimareis as uvas das separações. Porque jubileu é, santo será para vós; a novidade do campo comereis. Neste ano do jubileu tornareis cada um à sua possessão. $\mathrm{E}$ quando venderdes alguma coisa ao vosso próximo, ou a comprardes da mão do vosso próximo, ninguém engane a seu irmão; Conforme ao número dos anos, desde o jubileu, comprarás ao teu próximo; e conforme o número dos anos das colheitas, ele a venderá a ti. Conforme se multipliquem os anos, aumentarás o seu preço, e conforme à diminuição dos anos abaixarás o seu preço; porque conforme o número das colheitas é que ele te vende. Ninguém, pois, engane ao seu próximo; mas terás temor do teu Deus; porque eu sou o Senhor vosso Deus. E observareis os meus estatutos, e guardareis os meus juízos, e os cumprireis; assim habitareis seguros na terra. E a terra dará o seu fruto, e comereis a fartar, e nela habitareis seguros. E se disserdes: Que comeremos no ano sétimo? Eis que não havemos de semear nem fazer a nossa colheita; Então eu mandarei a minha bênção sobre vós no sexto ano, para que dê fruto por três anos, E no oitavo ano semeareis, e comereis da colheita velha até ao ano nono; até que venha a nova colheita, comereis a velha. Também a terra não se venderá em perpetuidade, porque a terra é minha; pois vós sois estrangeiros e peregrinos comigo. Portanto em toda a terra da vossa possessão dareis resgate à terra. Quando teu 
irmão empobrecer e vender alguma parte da sua possessão, então virá o seu resgatador, seu parente, e resgatará o que vendeu seu irmão. E se alguém não tiver resgatador, porém conseguir o suficiente para o seu resgate, então contará os anos desde a sua venda, e o que ficar restituirá ao homem a quem a vendeu, e tornará à sua possessão. Mas se não conseguir o suficiente para restituir-lha, então a que foi vendida ficará na mão do comprador até ao ano do jubileu; porém no ano do jubileu sairá, e ele tornará à sua possessão. $E$, quando alguém vender uma casa de moradia em cidade murada, então poderá resgatá-la até que se cumpra o ano da sua venda; durante um ano inteiro será lícito o seu resgate. Mas, se, cumprindo-se lhe um ano inteiro, ainda não for resgatada, então a casa, que estiver na cidade que tem muro, em perpetuidade ficará ao que a comprou, pelas suas gerações; não sairá no jubileu. Mas as casas das aldeias que não têm muro ao redor, serão estimadas como o campo da terra; para elas haverá resgate, e sairão no jubileu. Mas, no tocante às cidades dos levitas, às casas das cidades da sua possessão, direito perpétuo de resgate terão os levitas. E se alguém comprar dos levitas, uma casa, a casa comprada e a cidade da sua possessão sairão do poder do comprador no jubileu; porque as casas das cidades dos levitas são a sua possessão no meio dos filhos de Israel. Mas o campo do arrabalde das suas cidades não se venderá, porque lhes é possessão perpétua. (Levítico 25:8-34)

No tocante às leis sobre os dízimos e colheitas, o zelo de Deus por seu povo se torna mais evidente. Nas festas das Semanas (Colheita), os primeiros frutos eram dedicados ao Senhor e era responsabilidade do chefe da família possibilitar que os levitas e os pobres partilhassem das bênçãos materiais. Durante a colheita, as famílias deveriam deixar nos campos os grãos de cereais que caíssem, a fim de que os pobres pudessem recolhê-los e tivessem 
o que comer. Para as refeições perante o Senhor, eram convidados os levitas, pobres, estrangeiros, servos, órfãos e viúvas.

Certamente darás os dízimos de todo o fruto da tua semente, que cada ano se recolher do campo. E, perante o Senhor teu Deus, no lugar que escolher para ali fazer habitar o seu nome, comerás os dízimos do teu grão, do teu mosto e do teu azeite, e os primogênitos das tuas vacas e das tuas ovelhas; para que aprendas a temer ao Senhor teu Deus todos os dias. E quando o caminho te for tão comprido que os não possas levar, por estar longe de ti o lugar que escolher o Senhor teu Deus para ali pôr o seu nome, quando o Senhor teu Deus te tiver abençoado; Então vende-os, e ata o dinheiro na tua mão, e vai ao lugar que escolher o Senhor teu Deus; E aquele dinheiro darás por tudo o que deseja a tua alma, por vacas, e por ovelhas, e por vinho, e por bebida forte, e por tudo o que te pedir a tua alma; come-o ali perante o Senhor teu Deus, e alegra-te, tu e a tua casa; Porém não desampararás o levita que está dentro das tuas portas; pois não tem parte nem herança contigo. Ao fim de três anos tirarás todos os dízimos da tua colheita no mesmo ano, e os recolherás dentro das tuas portas; Então virá o levita (pois nem parte nem herança tem contigo), e o estrangeiro, e o órfão, e a viúva, que estão dentro das tuas portas, e comerão, e fartar-seão; para que o Senhor teu Deus te abençoe em toda a obra que as tuas mãos fizerem. (Deuteronômio 14:22-29)

Quando também fizerdes a colheita da vossa terra, o canto do teu campo não segarás totalmente, nem as espigas caídas colherás da tua sega. Semelhantemente não rabiscarás a tua vinha, nem colherás os bagos caídos da tua vinha; deixá-los-ás ao pobre e ao estrangeiro. Eu sou o Senhor vosso Deus. (Levítico 19:9,10) 
Essas medidas revelavam uma justiça social tão relevante quanto a pessoal e aos padrões morais:

Plantem e colham em sua terra durante seis anos, mas no sétimo deixem-na descansar sem cultivá-la. Assim os pobres do povo poderão comer o que crescer por si, e o que restar ficará para os animais do campo. Façam o mesmo com as suas vinhas e com os seus olivais. (Êxodo 23:10,11).

Apontado como o livro mais antigo da Bíblia Sagrada, o livro de Jó revela a vontade de Deus no que concerne à misericórdia e à justiça de Deus em relação aos pobres: provisão de abrigo, alimento e vestimenta. No trecho seguinte, Jó demonstra sua retidão no modo como se compadecia dos necessitados:

Se retive o que os pobres desejavam, ou fiz desfalecer os olhos da viúva, Ou se, sozinho comi o meu bocado, e o órfão não comeu dele (Porque desde a minha mocidade cresceu comigo como com seu pai, e fui o guia da viúva desde o ventre de minha mãe), Se alguém vi perecer por falta de roupa, e ao necessitado por não ter coberta, Se os seus lombos não me abençoaram, se ele não se aquentava com as peles dos meus cordeiros, Se eu levantei a minha mão contra o órfão, porquanto na porta via a minha ajuda, Então caia do ombro a minha espádua, e separe-se o meu braço do osso. (Jó 31:16-22)

O profeta Ezequiel condena a maneira como os pobres eram tratados e apresenta uma lista de atitudes indispensáveis para viver de modo justo e correto:

Não oprimindo a ninguém, tornando ao devedor a coisa penhorada, não roubando, dando o seu pão ao faminto e cobrindo ao nu com vestes; não dando o seu dinheiro à usura, não recebendo juros, desviando a sua mão da injustiça e fazendo verdadeiro juízo entre homem e homem; andando nos meus estatutos, 
guardando os meus juízos e procedendo retamente, o tal justo, certamente, viverá, diz o Senhor Deus. (Ezequiel 18:7-9)

Em diversas passagens do livro de Salmos, Deus é apresentado como defensor dos fracos e é exaltado por prometer socorrer os necessitados.

Porque a palavra do Senhor é reta, e todo o seu proceder é fiel. Ele ama a justiça e o direito; a terra está cheia da bondade do Senhor. (Salmos $33: 4,5)$

Reparte generosamente com os pobres; a sua justiça dura para sempre; seu poder será exaltado em honra. (Salmos 112:9)

Que faz justiça aos oprimidos e dá pão aos que têm fome. O Senhor liberta os encarcerados. $O$ Senhor abre os olhos aos cegos, o Senhor levanta os abatidos, o Senhor ama os justos. $O$ Senhor guarda o peregrino, ampara o órfão e a viúva, porém transtorna o caminho dos ímpios. (Salmos 146:7-9)

O livro de Provérbios alerta os homens a não pecarem contra Deus, notadamente quando se oprime ou ignora os necessitados. Por outro anima-os a ajudá-los e defendê-los, pois Deus recompensa àqueles que cuidam dos pobres.

Aquele que oprime o pobre com isso despreza o seu Criador, mas quem ao necessitado trata com bondade honra a Deus. (Provérbios 14:31)

Quem trata bem os pobres empresta ao Senhor, e ele o recompensará. (Provérbios 19:17)

Erga a voz em favor dos que não podem defender-se, seja o defensor de todos os desamparados. Erga a voz e julgue com justiça; defenda os direitos dos pobres e dos necessitados. (Provérbios 31:8,9) 
Entre os profetas, o zelo pelos menos favorecidos é bastante frequente. Muitos deles, como Isaías, Jeremias, Zacarias, Miqueias e Amós denunciaram os ricos de aproveitarem-se dos fracos e vulneráveis, mesmo quando cumprindo as leis, conhecendo a Lei e participando da adoração (KELLER, 2013: p. 67). Esses profetas ensinaram que a misericórdia em relação ao pobre é uma evidência da aliança com Deus, marca da verdadeira fé, e que o descaso com os menos favorecidos é um pecado semelhante ao adultério e à idolatria. Em Isaías 58:6-8, encontra-se a seguinte exortação:

Porventura não é este o jejum que escolhi, que soltes as ligaduras da impiedade, que desfaças as ataduras do jugo e que deixes livres os oprimidos, e despedaces todo o jugo? Porventura não é também que repartas o teu pão com o faminto, e recolhas em casa os pobres abandonados; e, quando vires o nu, o cubras, e não te escondas da tua carne? Então romperá a tua luz como a alva, e a tua cura apressadamente brotará, e a tua justiça irá adiante de ti, e a glória do Senhor será a tua retaguarda. (Isaías 58:6-8)

Portanto, visto que pisais o pobre e dele exigis um tributo de trigo, edificastes casas de pedras lavradas, mas nelas não habitareis; vinhas desejáveis plantastes, mas não bebereis do seu vinho. Porque sei que são muitas as vossas transgressões e graves os vossos pecados; afligis o justo, tomais resgate, e rejeitais os necessitados na porta. (Amós 5:11,12)

Miqueias 6.8 ensina a maneira que Deus quer que vivamos: amando-o com humildade, ter intimidade com Ele e obedecer às suas leis. Implica também, conforme Keller (2013, p.24-25), praticar a justiça (do hebraico mishpat, que enfatiza a ação) e amar a misericórdia (do hebraico chesedh, a atitude, o motivo por trás da ação). O significado básico do termo mishpat revela que devemos tratar as pessoas com imparcialidade, tanto no tocante a punições quanto ao assegurar o direito das pessoas, independentemente de raça e posição social. De acordo com a Bíblia, a justiça de uma sociedade é avaliada segundo o tratamento dado ao "quarteto da vulnerabilidade" (KELLER, 2013, p.26), grupos de menor poder 
social nas sociedades agrárias pré-modernas, formado por órfãos, estrangeiros, viúvas e pobres. Miqueias revela o que o Senhor exige do seu povo:

Agradar-se-á o Senhor de milhares de carneiros, ou de dez mil ribeiros de azeite? Darei o meu primogênito pela minha transgressão, o fruto do meu ventre pelo pecado da minha alma? Ele te declarou, ó homem, o que é bom; e que é o que o Senhor pede de ti, senão que pratiques a justiça, e ames a benignidade, e andes humildemente com o teu Deus? (Miqueias 6:7,8)

No Novo Testamento, os Evangelhos relatam a compaixão de Jesus pelos que recorriam a Ele, em busca de cura e de auxílio, confirmando o que fora predito pelos profetas, ao anunciarem o modo como o Messias seria conhecido: pela sua misericórdia para com os pobres (Is 11.1-4; 61.1-2). Ao responder a João Batista, Jesus destacou, como prova de sua messianidade, que o Evangelho era proclamado entre os pobres e os vulneráveis eram atendidos em suas necessidades:

E Jesus, respondendo, disse-Ihes: Ide e anunciai a João o que estais ouvindo e vendo: os cegos veem, os coxos andam, os leprosos são purificados, os surdos ouvem, os mortos são ressuscitados, e aos pobres está sendo pregado o evangelho. (Mateus 11:4,5)

$E$, vendo as multidões, teve grande compaixão delas, porque andavam cansadas e desgarradas, como ovelhas que não têm pastor. (Mateus 9:36)

E, Jesus, saindo, viu uma grande multidão, e possuído de íntima compaixão para com ela, curou os seus enfermos. (Mateus 14:14)

Então Jesus, movido de íntima compaixão, tocouIhes nos olhos, e logo seus olhos viram; e eles o seguiram. (Mateus 20:34) 
Mas, quando fizeres convite, chama os pobres, aleijados, mancos e cegos, E serás bemaventurado; porque eles não têm com que o recompensar; mas recompensado te será na ressurreição dos justos. (Lucas 14:13,14)

Também em suas parábolas e ensinos, o nosso Senhor enfatizou a importância do cuidado com os necessitados, demonstrando o mesmo amor de Deus para com os pobres manifestado no Antigo Testamento. Ele se interessa e ama profundamente os pobres e oprimidos (LC 7,11-16), bem como as pessoas marginalizadas da sociedade (Mt 9,13; LC 7.36ss).

E aconteceu que, no dia seguinte, ele foi à cidade chamada Naim, e com ele iam muitos dos seus discípulos, e uma grande multidão; $E$, quando chegou perto da porta da cidade, eis que levavam um defunto, filho único de sua mãe, que era viúva; e com ela ia uma grande multidão da cidade. E, vendo-a, o Senhor moveu-se de íntima compaixão por ela, e disse-lhe: Não chores. E, chegando-se, tocou o esquife (e os que o levavam pararam), e disse: Jovem, a ti te digo: Levanta-te. E o que fora defunto assentou-se, e começou a falar. E entregou-o à sua mãe. $E$ de todos se apoderou o temor, e glorificavam a Deus, dizendo: Um grande profeta se levantou entre nós, e Deus visitou o seu povo. (Lucas 7:1116)

Em suas parábolas, Cristo nos ensinou a amar nossos inimigos, a fazer o bem a quem nos persegue, ministrou às multidões, por meio de palavras e de ações, e, mesmo priorizando a pregação para os israelitas, pregou e curou judeus e não judeus. É importante ressaltar que não se trata de conseguir a salvação por meio de boas obras, mas de entender que essas ações em favor do desvalido sejam evidências de salvação, de fé verdadeira. Cristo ensinava que o encontro com a graça leva inevitavelmente a uma vida de justiça (KELLER, 2013, p. 66). Nesse sentido, do mesmo modo que foi enviado pelo Pai com uma missão, Jesus comissionou a igreja para realizar sua obra (Jo 20:21). Essa missão consiste em fazer discípulos e deve ser executada por meio do batismo e do 
ensino, enquanto se realizam as atividades diárias na caminhada cristã (Mt 28:19-20). O Espírito Santo capacita a igreja para realizar essa tarefa em cidades (Jerusalém), em outros estados e países (Judéia e Samaria) e qualquer lugar aonde Deus enviar, ou seja, os confins da terra (Atos 1:8). Entre as recomendações de Jesus, o cuidado com o próximo se destaca:

Curem os doentes que ali houver e digam-Ihes: $O$ Reino de Deus está próximo de vocês. (Lucas 10:9)

Amai, porém, os vossos inimigos, fazei o bem e emprestai, sem esperar nenhuma paga; será grande o vosso galardão, e sereis filhos do Altíssimo. Pois ele é benigno até para com os ingratos e maus. Sede misericordiosos, como também é misericordioso vosso Pai. (Lucas 6:3536)

Em diversas outras passagens do Novo Testamento, os cristãos são exortados a atender às necessidades físicas e econômicas dos irmãos. No livro de Atos, o relato de Lucas a respeito do testemunho dos primeiros cristãos revela que aquela igreja seguiu em tudo o exemplo de Jesus no seu cuidado para com os necessitados, tanto em palavras quanto em ações, obedecendo ao chamado do Cristo no tocante à justiça e à misericórdia.

Todos os que criam mantinham-se unidos e tinham tudo em comum. Vendendo suas propriedades e bens, distribuíam a cada um conforme a sua necessidade. (Atos 2:44,45)

Não havia pessoas necessitadas entre eles, pois os que possuíam terras ou casas as vendiam, traziam o dinheiro da venda e o colocavam aos pés dos apóstolos, que o distribuíam segundo a necessidade de cada um. (Atos 4:34,35)

Tomando-a pela mão, ajudou-a a pôr-se de pé. Então, chamando os santos e as viúvas, apresentou-a viva. Este fato se tornou conhecido 
em toda a cidade de Jope, e muitos creram no Senhor. (Atos 9:41,42)

Em tudo o que fiz, mostrei-Ihes que mediante trabalho árduo devemos ajudar os fracos, lembrando as palavras do próprio Senhor Jesus, que disse: 'Há maior felicidade em dar do que em receber'. Atos 20:35

As passagens anteriores nos lembram Deuteronômio 15.4 "Não haverá pobre algum no teu meio. " Nesse versículo, Deus expressa seu amor pelos desprovidos, afirmando que, se o povo Ihe obedecesse como deveria, a pobreza seria extinta no meio dele. Nas cartas dos apóstolos, como Paulo, João, Tiago, enviadas às igrejas, incentivam-se ações de compromisso social dos cristãos, admoestando-os a lembrar dos pobres.

Somente pediram que nos lembrássemos dos pobres, o que me esforcei por fazer. (Gálatas 2:10)

No meio da mais severa tribulação, a grande alegria e a extrema pobreza deles transbordaram em rica generosidade. Pois dou testemunho de que eles deram tudo quanto podiam, e até além do que podiam. Por iniciativa própria eles nos suplicaram insistentemente o privilégio de participar da assistência aos santos. (2 Coríntios 8:2-4)

Nisto conhecemos o que é o amor: Jesus Cristo deu a sua vida por nós, e devemos dar a nossa vida por nossos irmãos. Se alguém tiver recursos materiais e, vendo seu irmão em necessidade, não se compadecer dele, como pode permanecer nele o amor de Deus? Filhinhos, não amemos de palavra nem de boca, mas em ação e em verdade. (1 João 3:16-18)

Entre outros cuidados com os necessitados estão a distribuição diária de alimentos, a partilha dos bens e o cuidado com as viúvas, com os estrangeiros e com os enfermos. 
E não nos cansemos de fazer o bem, pois no tempo próprio colheremos, se não desanimarmos. Portanto, enquanto temos oportunidade, façamos o bem a todos, especialmente aos da família da fé. (Gálatas $6: 9,10)$

Ordene aos que são ricos no presente mundo que não sejam arrogantes, nem ponham sua esperança na incerteza da riqueza, mas em Deus, que de tudo nos provê ricamente, para a nossa satisfação. Ordene-Ihes que pratiquem o bem, sejam ricos em boas obras, generosos e prontos para repartir. (1 Timóteo 6:17,18)

A religião que Deus, o nosso Pai aceita como pura e imaculada é esta: cuidar dos órfãos e das viúvas em suas dificuldades e não se deixar corromper pelo mundo. (Tiago 1:27)

Se alguém tiver recursos materiais e, vendo seu irmão em necessidade, não se compadecer dele, como pode permanecer nele o amor de Deus? Filhinhos, não amemos de palavra nem de boca, mas em ação e em verdade. (1 João 3:17,18)

Se um irmão ou irmã estiver necessitando de roupas e do alimento de cada dia e um de vocês Ihe disser: "Vá em paz, aqueça-se e alimente-se até satisfazer-se", sem, porém, Ihe dar nada, de que adianta isso? (Tiago 2:15,16)

E Deus é poderoso para fazer que lhes seja acrescentada toda a graça, para que em todas as coisas, em todo o tempo, tendo tudo o que é necessário, vocês transbordem em toda boa obra. Como está escrito: "Distribuiu, deu os seus bens aos necessitados; a sua justiça dura para sempre". Aquele que supre a semente ao que semeia e o pão ao que come, também lhes suprirá e aumentará a semente e fará crescer os 
frutos da sua justiça. Vocês serão enriquecidos de todas as formas, para que possam ser generosos em qualquer ocasião e, por nosso intermédio, a sua generosidade resulte em ação de graças a Deus. (2 Coríntios 9:8-11)

Ordene aos que são ricos no presente mundo que não sejam arrogantes, nem ponham sua esperança na incerteza da riqueza, mas em Deus, que de tudo nos provê ricamente, para a nossa satisfação. Ordene-Ihes que pratiquem o bem, sejam ricos em boas obras, generosos e prontos para repartir. (1 Timóteo 6:17,18)

E consideremo-nos uns aos outros para incentivar-nos ao amor e às boas obras. (Hebreus 10:24)

De que adianta, meus irmãos, alguém dizer que tem fé, se não tem obras? Acaso a fé pode salválo? Se um irmão ou irmã estiver necessitando de roupas e do alimento de cada dia e um de vocês Ihe disser: "Vá em paz, aqueça-se e alimente-se até satisfazer-se", sem, porém, Ihe dar nada, de que adianta isso? Assim também a fé, por si só, se não for acompanhada de obras, está morta. (Tiago 2:14-17)

Conforme Blainey (2012), a maneira prática com que os cristãos ajudavam os pobres, famintos, doentes e órfãos contribuiu para atrair pessoas de fora da comunidade, conquistando amigos e simpatizantes.

Todos os dias, continuavam a reunir-se no pátio do templo. Partiam o pão em suas casas, e juntos participavam das refeições, com alegria e sinceridade de coração, louvando a Deus e tendo a simpatia de todo o povo. E o Senhor Ihes acrescentava todos os dias os que iam sendo salvos. (Atos 2:46,47) 
Após o início da igreja, seu testemunho se expande de Jerusalém para a Judeia e Samaria e se desloca para diversas regiões do Império Romano, inclusive Roma. Além da dedicação e da proclamação da Palavra de Deus, a vida de oração e de comunhão da comunidade, bem como o modelo de assistência dada às pessoas desamparadas por Cristo e pelos primeiros cristãos tornaram-se base para a Igreja durante a Idade Média.

\section{O CUIDADO COM OS POBRES NA IGREJA MEDIEVAL}

A igreja primitiva, após o martírio dos apóstolos Pedro e Paulo em Roma, tentava sobreviver às perseguições decorrentes de ser uma religião proibida em meio a religiões mais antigas. No primeiro e segundo séculos, as obras de caridade e assistência aos irmãos e aos necessitados integraram a vida cristã, caracterizando a Igreja (KUHN, 2013). Nos dois primeiros séculos, a igreja se expandiu rapidamente, em grande parte, decorrente do senso de comunidade e da boa vontade dos cristãos em relação aos necessitados, conforme atestado por Blainey (2012, p. 63). Outro fator que contribuiu para essa expansão, ainda segundo o autor, transcorreu das grandes epidemias, como varíola, sarampo assolaram o império romano nos séculos iniciais do novo milênio, causando inúmeras mortes. Os cristãos eram reconhecidos pela assistência dada às populações afligidas durante as invasões dos bárbaros e em outras calamidades. Nesse cenário de desolação, Blainey destaca, os cristãos se evidenciaram pela

[...] Enquanto as religiões pagãs raramente ofereciam algum tipo de ajuda quando os fiéis adoeciam, muitos cristãos - mulheres, em especial - se dispunham a cuidar dos enfermos e alimentá-los. [...] Ao cuidar de doentes e moribundos sem exceção, qualquer que fosse a religião professada por eles, os cristãos conquistaram amigos e simpatizantes. Eles demonstravam uma excepcional confiança na cura pela oração e pela unção. (BLAINEY, 2012, p. 63)

Entre os documentos sobreviventes, apontados como os mais antigos, com exceção dos Evangelhos canônicos, estão o 
Didaquê, o Evangelho de Tomé e a epístola conhecida como I Clemente, endereçada aos cristãos da cidade de Corinto. A epístola, escrita provavelmente entre o final do século I e o início do século II, fala de cristãos que se venderam como escravos a fim de socorrer os necessitados:

Dê a quem lhe pede e não peças de volta pois o Pai quer que os seus bens sejam dados a todos. (DIDAQUÉ 1:6)

Não repelirás o indigente, mas antes repartirás tudo com teu irmão, não considerando nada como teu, pois, se divides os bens da imortalidade, quanto mais o deves fazer com os corruptíveis [Cf At 4,32; Heb 13,16]. (DIDAQUÉ 14:8)

Conhecemos muitos dentre os nossos que se entregaram à prisão para resgatarem outros. Muitos se entregaram à escravidão para sustentar os demais com o dinheiro pago. (I CLEMENTE, cap.LV, v.2)

Após a oficialização do cristianismo por Constantino, o conceito cristão de caridade, estranho em qualquer texto da lei romana, assumiu uma dimensão social, de forma que o auxílio a cristãos e não cristãos fosse organizado por instituições de caridade com o patrocínio eclesiástico. Blainey (2012, p.149) comenta sobre o papel e as atividades da Igreja Católica no período:

[...] Atualmente, não existe instituição, seja cultural, religiosa ou educacional, que se compare à situação daquela época. Como em uma versão inicial da assistência social do Estado, a igreja mantinha albergues para idosos e orfanatos para os jovens, hospitais para os enfermos de todas as idades; leprosários; e hospedarias onde os peregrinos podiam encontrar cama e comida por bom preço. 
Para atuar em tantas frentes, a Igreja recolhia contribuições em forma de taxas ou dízimos. Os cristãos podiam colaborar doando bens à Igreja. Dessa forma, por um lado, a doação de dinheiro e terras cooperou para o cumprimento da missão social e, por outro lado, colaborou para o crescimento do poder e da fortuna da instituição eclesiástica.

Kuhn (2013, p. 41) faz referência a esse fundo comunitário constituído a partir de doação, em que se distribuíam donativos, não só às viúvas, órfãos, mas, principalmente, aos prisioneiros, escravos que estavam sofrendo por amor a Cristo, visitavam doentes, auxiliavam vítimas de pragas e eram hospitaleiros: Essa obra de caridade não era uma mera teoria, mas uma realidade viva, não era apenas conceitos, mas prática concreta, feita em nome de Cristo e seguida a Seu exemplo e dos apóstolos. Ao longo do tempo, as esmolas, bem como as obras de caridade, foram perdendo seu caráter de generosidade e de cuidado com o próximo, passando a ter um caráter meritório.

$\mathrm{Na}$ época medieval, a igreja incentivava a obediência aos mandamentos divinos, a fuga ao pecado e a caridade com os pobres. Resultante dessas ações em favor dos necessitados, surgiram escolas, orfanatos, conventos e mosteiros onde, além de outras atividades, cuidava-se dos doentes, alimentavam-se os famintos e abrigavam-se os peregrinos. Muitos homens renunciavam ao mundo, passando a viver nos mosteiros, dedicando-se exclusivamente a Deus.

O monastério oferecia mais segurança, nesse período de fome e pobreza; dessa forma, muitos cristãos eremitas buscavam a companhia de outros monges, em regiões isoladas, numa vida cheia de regras e de renúncia ao mundo exterior. Muitos acreditavam ser necessário dominar o corpo, a fim de que o espírito e a alma triunfassem. Relatando sobre a vida nessas comunidades, Blainey afirma:

Os peregrinos ou os monges de outros mosteiros que estivessem em viagem eram tratados com generosa hospitalidade. Pacômio considerava as mulheres capazes de perturbar a paz do mosteiro. No entanto, se uma delas chegasse ao anoitecer, "seria crueldade mandá-la embora". Assim, acomodava-se a viajante em um aposento para hóspedes, separado por um muro ou uma cerca. (BLAINEY, 2012, p. 78) 
Inicialmente, apenas pelos homens viviam nos monastérios, mas gradativamente, as mulheres, principalmente viúvas e solteiras, também passaram a formar grupos, unindo-se em mosteiros exclusivamente femininos, onde poderiam cuidar dos membros da congregação que ficassem doentes e aprender a ler, a fim de transmitir a Bíblia às amigas.

O cotidiano dos monges, em geral, além dos trabalhos relacionados à administração e manutenção dos mosteiros, consistia em orações e estudos. No tocante ao cuidado com os pobres, Blainey (2012) ressalta, entre outros, o papel desempenhado pelo mosteiro francês de Cluny:

Os monges atendiam os famintos que batiam à porta do mosteiro e ajudavam os pobres da vizinhança. [...] Para os pedintes, a cozinha do mosteiro preparava regularmente uma dúzia de tortas enormes, além de distribuir pão e sopa quente. (BLAINEY, 2012, p.108)

No século VI, Bento, um monge nascido em Nórcia, na Itália, fundou o Mosteiro de Monte Cassino e se tornou um dos mais influentes do seu tempo. Defendia que os irmãos deviam estar sempre ocupados, seja orando, seja trabalhando. Entre os monges beneditinos, cultivou-se a prática de fazer cirurgias e o cultivo de ervas medicinais, fundaram hospitais e enfermarias e se tornaram os principais cuidadores da saúde dos habitantes da região que circundava o mosteiro.

No século XI, São Francisco de Assis instruía as pessoas para que, aqueles que possuíssem bens, doassem suas riquezas aos necessitados, dedicando-se a ajudar os mais desprezados, naquele contexto, os leprosos. Suas palavras ainda repercutem: "Proclamem o Evangelho e, se necessário, usem palavras."

Em várias partes da Europa, aumentou o número de mosteiros, que recebiam doações em diferentes tipos de bens, como terras, animais, livros, aumentando a riqueza, o conforto e o poder dos monges. No decorrer dos anos, controvérsias religiosas diversas causaram discordâncias entre o clero, culminando com o Cisma do Oriente, que provocou o surgimento de Igreja do Oriente e a do Ocidente. Essas Igrejas tomaram caminhos diferentes. 


\section{A RESPONSABILIDADE SOCIAL NA VISÃO REFORMADA}

O surgimento de novos rituais e doutrinas viriam a causar novas divergências entre as igrejas cristãs. A partir do século XVI, ocorreu na Europa o movimento da Reforma Protestante, originada por Martinho Lutero, que tem como marco inicial uma discussão sobre a salvação pela fé ou salvação pelas obras. Os protestantes ressaltaram a fé, em detrimento das obras, com o intuito de combater os exageros sobre a prática de boas obras na teologia medieval. Com a Reforma, surgiram novas ênfases teológicas: valorização da vida diária, apresentação de nova ética do trabalho, pregação do fim da distinção entre clérigos e leigos, ênfase na educação, embora mantendo a tradição de envolver-se socialmente.

Na geração seguinte à de Lutero, João Calvino é reconhecido como um dos maiores líderes da Reforma; seu vasto conhecimento como teólogo, pregador e pastor, aliados à sua prática pastoral, serviu como suporte para embasar seu trabalho na reconstrução do papel da Igreja cristã em uma sociedade mergulhada em grandes problemas sociais. Apoiou instituições sociais de Genebra, além de escrever sobre questões sociais nas Institutas, em comentários e em sermões. Conforme Lopes (2011), por ter uma visão ampla e amadurecida intelectualmente, Calvino esforçou-se para discernir qual o papel da Igreja cristã no contexto de uma realidade social permeada pela pobreza, miséria, opressão, corrupção. Em sua teologia social desenvolveu alguns pontos como sendo responsabilidade da Igreja.

Na visão de Calvino, o ponto inicial e fonte dos problemas que afetavam o homem e a sociedade como um todo, estavam enraizados na natureza decaída do homem, provocada pelo pecado na Queda do Éden. Toda ordem da criação foi afetada pelo pecado de Adão, causando caos e profundas perturbações na bela e perfeita criação de Deus. Um segundo ponto está relacionado a restauração da criação através de Jesus Cristo. O Cristo vivo e exaltado é Senhor de todo o universo. Sua obra de restauração não se limita apenas à nova vida dada ao indivíduo, mas abrange a restauração de todo o universo - o que inclui a ordem social e econômica. Outro ponto importante para Calvino é que, se Cristo era o Senhor de toda a existência humana, era dever da Igreja dar atenção às questões sociais e políticas. André Biélier resume a doutrina do reformador sobre o dinheiro: 
Associado com Cristo pela fé, o ser humano restaurado na sua dignidade de filho de Deus redescobre sua justa relação com o próximo. Recebe, dessarte, uma compreensão nova e exata da função do dinheiro, instrumento de Deus para o sustento da sociedade. Compreende que o dinheiro deve ser sujeitado a fim de ser consagrado a Deus e ao próximo. Ao nível pessoal, essa descoberta impõe ao ser humano uma rigorosa autodisciplina. (BIÉLIER, 1961, p. 35)

A restauração da sociedade inaugurada por Cristo ocorre inicialmente no seio da Igreja. É na Igreja que a ordem primitiva da sociedade, tal qual Deus havia estabelecido, tende a ser restaurada. $\mathrm{Na}$ Igreja, as diferenças exacerbadas entre as classes sociais, econômicas e raciais, bem como os preconceitos delas procedentes, desaparecem, pois, Cristo de todos faz um único povo.

DeYoug; Gilbert (2012) observam que cuidar dos pobres e dos aflitos é a coisa bíblica a fazermos. Os autores ressaltam o resumo feito por Calvino sobre essa responsabilidade dos cristãos:

Retidão e justiça são divididas em duas partes: primeira, não devemos prejudicar ninguém; segunda, devemos dar nossa riqueza e abundância aos pobres e necessitados. E essas duas coisas têm de andar juntas, pois não basta abster-se de atos de injustiça, se você recusa sua assistência aos necessitados; também será inútil prestar ajuda aos necessitados, se, ao mesmo tempo, você rouba aquilo que dá aos outros... Portanto, essas duas partes têm de ser mantidas juntas, para que nosso amor para com o próximo seja aprovado e aceito por Deus. (CALVINO, apud DEYOUG; GILBERT, 2012, p.206)

De acordo com Lopes (2011), são três os aspectos fundamentais da responsabilidade da Igreja na visão de Calvino: um ministério didático, um político, e um social. O primeiro, correspondente à Mordomia Cristã, consiste na instrução pública e particular, no ensino bíblico sobre a gerência dos bens concedidos por Deus ao Estado e ao indivíduo. O segundo aspecto, 
o político, consiste na responsabilidade da Igreja de vigiar o Estado, ou seja, advertir as autoridades nos casos de abuso do poder e de injustiça, contra os pobres, os fracos e os oprimidos. O terceiro, o aspecto social, está relacionado à assistência social, no sentido de que é função da Igreja envolver-se em cuidar dos necessitados, sem distinguir entre os que integram a igreja e os de fora. Aliado a esse pensamento, Biélier 1961, p.24) afirma

Calvino é um dos teólogos cristãos que melhor definiu o direito e o dever de resistência ao Estado. Sob qualquer regime político que seja, os cristãos devem opor-se com vigor às exigências do Estado toda vez que essas contrariem a vontade de Deus.

Na Europa, segundo Souza (2011), as reformas caracterizaram-se pelo cuidado com os necessitados, o que teve como consequência na maioria das cidades em que 0 protestantismo prevaleceu, uma legislação social, com apoio a exilados e proteção aos carentes. Em Genebra, com os calvinistas, as questões sociais foram prioritárias. Defendem-se, entre outros, os princípios de que a comunidade deve redistribuir os recursos dados por Deus, com vistas ao bem comum. Além disso, os cristãos são convocados a serem solidários e generosos, e não gananciosos e insensíveis.

Nos séculos XVIII e XIX, grandes avivamentos atingiram diferentes denominações na Europa. Na região germânica, o movimento pietista propunha mudanças na vida religiosa do povo e em muitos hábitos eclesiásticos. Verifica-se, tanto na Alemanha como na Inglaterra, leitura diária da Bíblia nos lares, maior simplicidade na pregação, além da preocupação social, entendendo que uma vida piedosa e próxima de Deus deve obrigatoriamente motivar os cristãos a agir em benefício do mais necessitado, resultando, além de uma intensa participação política, na construção de escolas, creches e hospitais. Os metodistas, por sua vez, enfatizavam a necessidade de uma experiência real com Deus, que levasse o crente a cumprir as Escrituras, inclusive no que concerne à realização de boas ações em favor dos fracos.

Na Inglaterra, com João e Carlos Wesley, metodistas, e nos Estados Unidos, liderados por George Whitefied e Jonathan Edward (1740), esses movimentos, conforme Fountain (2008), provocaram um intenso envolvimento social, trazendo, entre as consequências: 
reforma nas prisões, luta contra o trabalho infantil, emancipação das mulheres, educação, com a criação de escolas e universidades, eliminação do tráfico de escravos e abolição da escravidão industrial. Souza também reforça as consequências desses avivamentos:

[...] há uma preocupação crescente com as condições da sociedade, especialmente em relação aos mais pobres e que sofrem. Assim, ocorreram diversas lutas por reformas sociais, como defesa de escolas públicas para todos, melhorias nos presídios e abolição da escravidão. Souza (2011, p. 152)

Conforme o autor, nos Estados Unidos e na Europa, a influência do lluminismo, a urbanização e outros problemas decorrentes da Revolução Industrial, como o alcoolismo, a violência, a prostituição e o aumento do número de crianças órfãs ou abandonadas resultaram na construção de creches e lares para mães solteiras, na assistência a mendigos e em outras atividades. Além das já citadas, Goode (2008) aponta outras consequências de ministérios de justiça social da igreja: reforma trabalhista para adultos e crianças, emancipação da mulher e transformações culturais. Para o autor

Uma avaliação dos últimos duzentos anos da história da Igreja, avivamentos e reformas, também revela a profundidade da influência do Evangelho e do povo de Deus sobre a sociedade civil e suas instituições. (GOODE, 2008, p.344)

$\mathrm{Na}$ América Latina, os missionários protestantes que vieram para o Brasil, mantiveram-se, de início, relativamente isolados com sua fé. Segundo Silva (1996, p. 132); só a partir da segunda metade do século XIX, com a implantação de missões de denominações históricas, como congregacionais, presbiterianas, metodistas e batistas, a presença protestante no território brasileiro causaria maior impacto.

Segundo Souza (2011), o protestantismo brasileiro, desde sua implantação até a meados do século $X X$, considerou as implicações sociais do Evangelho. A estratégia missionária usava a educação como forma de levar o progresso e refletia o pensamento iluminista e a defesa das liberdades pessoais. 
Predominaram, na época, ações e reflexões filantrópicas e obras assistencialistas, baseadas na atitude de cada crente.

Ainda de acordo com Souza (2011, p. 154), mudanças nas condições sociais brasileiras, na década de 1950, provocavam reflexões não somente de intelectuais estudantes e políticos, mas também dos protestantes, que buscaram entender a nação e procurar os caminhos para transformá-la, de modo a melhorar a vida de todos, articulando a ideia de responsabilidade social da Igreja e do cristão, levando-os, inclusive, ao engajamento político na sociedade, de modo a agir além da filantropia e do assistencialismo. No entanto, nos anos subsequentes, embora a igreja permanecesse realizando obras sociais de cunho assistencialista, reduziu-se em grande parte a discussão em torno do assunto. Havia aqueles que entendiam que a missão da Igreja é exclusivamente espiritual, considerando a defesa de políticas públicas e a atuação social em benefício dos mais carentes uma associação com o comunismo ou mesmo uma tendência de esquerda. A questão da prioridade da missão da Igreja voltou ao centro das discussões.

Conflitos sociais e políticos, surgidos a partir dos anos de 1960, deram origens a movimentos socialistas e regimes de direita. No Brasil, desde sua implantação, no início do século XIX, até meados do século $X X$, o protestantismo incluiu implicações sociais do Evangelho na reflexão teológica, inserindo o pensamento iluminista e a defesa das liberdades pessoais. Como estratégia missionária, a educação, filantropia e obras assistencialistas foram fundamentais para levar ao progresso, criando escolas, creches, ambulatórios, hospitais e escolas agrícolas.

No século $X X$, dois movimentos teológicos cristãos - um ligado à Igreja Católica e outro relacionado com o movimento protestante - ambos com ênfase na ação social, destacaram-se no Brasil, refletindo o que acontecia na América Latina: a Teologia da Libertação, corrente teológica cristã católica que parte da premissa de que o Evangelho exige a opção pelos pobres, e a Teologia da Missão Integral, que considera que é missão da igreja levar o evangelho integral para o homem integral e para todos os homens.

A Teologia da Libertação surgiu a partir das décadas de 60 e 70 do século XX, no seio da igreja católica na América Latina. Tem sua origem associada ao teólogo peruano Gustavo Gutiérrez e é representada no Brasil por Leonardo Boff e por Frei Betto. Recebeu influência do Evangelho Social, de outras correntes de filosofia religiosa, desenvolvendo um movimento fundamentado na opção 
pelos pobres contra a pobreza e pela libertação. Nesse sentido, buscava interpretar os ensinamentos de Cristo em relação à libertação de condições econômicas, sociais e políticas injustas, ou seja, em lutar por justiça social, mas foram acusados de apoiar revoluções e lutas de classes.

Atribui-se a origem e o desenvolvimento da Teologia da Libertação a três fatores: primeiramente ao contexto histórico em que surgiu, repleto de conflitos políticos, econômicos e sociais; em segundo, ao uso do marxismo como instrumento de análise social; e em terceiro - mudanças ocorridas tanto na Igreja Católica, como o florescimento Comunidades Eclesiais de Base, quanto na sociedade, que permitiram o surgimento da teologia (BORGES, 2014). Essa teologia encontrou inúmeras oposições dentro do próprio catolicismo - notadamente nos pontificados de João Paulo II e Bento XVI - e da maior parte dos evangélicos, atribuídas à sua análise marxista, à percepção da salvação como libertação social e política, além de seu caráter, considerado excessivamente politizado.

A Teologia da Missão Integral, por sua vez, nasceu de movimentos trazidos para a América Latina pela missão protestante-evangélica dos séculos XIX e XX, buscando refletir sobre as missões a partir do contexto da América Latina.

Desde 1969, com o Primeiro Congresso Latino-americano de Evangelização - Clade I, depois, em 1970, com a criação da Fraternidade Teológica Latino-americana, e principalmente a partir do Pacto de Lausanne, teólogos evangélicos da América Latina passaram a influenciar o debate teológico e missiológico em nível mundial.

Em 1974, em Lausanne, na Suíça, durante o Congresso Mundial de Evangelização, foram apresentadas e discutidas diferentes posições sobre a prioridade da missão da Igreja: alguns defenderam a prioridade da evangelização; outros entenderam que a evangelização deve ser acompanhada de justiça social, embora esta esteja subordinada àquela e um terceiro grupo compreendeu que tanto a evangelização quanto a justiça social se complementam, sem que haja prioridade entre elas (CARVALHO et al, 2009 p. 18). As palestras realizadas por René Padilha e Samuel Escobar tinham o intuito de apresentar um modelo mais bíblico, sensível ao contexto da América Latina, e diferenciando-se do modelo tradicional de missão instalado nos círculos evangélicos. Lopes (2007) cita trechos das duas palestras, nas palavras respectivamente de Padilha e de Escobar: 
Nossa maior necessidade é um evangelho mais bíblico e uma igreja mais fiel. Poderemos nos despedir deste congresso com um belo conjunto de papéis e declarações que serão arquivadas e esquecidas, e com lembrança de um grande e impressionante encontro de âmbito mundial. Ou poderemos sair daqui com a convicção de que temos fórmulas mágicas para a conversão das pessoas. Eu pessoalmente espero em Deus que possamos sair daqui com uma atitude de arrependimento no que diz respeito à nossa escravidão ao mundo e ao nosso arrogante triunfalismo, com o senso de nossa incapacidade de sermos libertos dos grilhões a que estamos atados e, apesar disso, com grande confiança em Deus, o Pai de nosso Senhor Jesus Cristo, que "é poderoso para fazer infinitamente mais do que tudo quanto pedimos ou pensamos, conforme o seu poder que opera em nós, a ele seja a glória, na igreja e em Cristo Jesus, por todas as gerações, para todo o sempre". Amém. (PADILLA, apud LOPES, 2007, p. 14)

Samuel Escobar afirmou:

Uma espiritualidade sem discipulado nos aspectos diários da vida - sociais, econômicos e políticos -, é religiosidade e não cristianismo [...] De uma vez por todas, devemos rejeitar a falsa noção de que a preocupação com as implicações sociais do evangelho e as dimensões sociais do testemunho cristão resultam de uma falsa doutrina ou de uma ausência de convicção evangélica. Ao contrário, é o interesse pela integridade do Evangelho que nos motiva a acentuarmos a sua dimensão social". (ESCOBAR, apud LOPES, 2007, p. 15)

Para essa teologia, as missões feitas na América Latina deveriam ocupar-se globalmente com a realidade, com o contexto social, político, econômico, ou seja, considerar integralmente o ser 
humano, com tudo que está relacionado à sua realidade histórica e não apenas com a salvação de almas individuais.

A discussão iniciada no Congresso prosseguiu nos anos seguintes. No término do evento, foi elaborado o Pacto de Lausanne, redigido sob a direção de John Stott. Definiu-se, então, a posição dos evangélicos, afirmando-se o interesse pela ação social em favor dos pobres e necessitados, ao mesmo tempo em que acentuou a autoridade da Bíblia, a singularidade de Cristo e a necessidade da evangelização. Demonstrou-se que o evangelismo bíblico é inseparável da responsabilidade social, do discipulado cristão e da renovação da igreja.

A Teologia da Missão Integral foi amadurecendo e se desenvolvendo principalmente nas questões de evangelização e responsabilidades sociais. No entanto, não é totalmente acolhida no meio evangélico no Brasil, uma vez que muitos a consideram uma interpretação evangélica da Teologia da Libertação. No entanto, diferenças importantes separam essas duas teologias: enquanto a Teologia da Libertação centra-se na visão marxista, na filosofia de grandes pensadores e no engajamento de lutas revolucionárias que circundavam a América Latina, a Teologia da Missão Integral tem unicamente a Bíblia como referencial para delinear a missão da Igreja, o que se reflete sobre ações efetivas de evangelização e responsabilidade social (BORGES, 2014, p. 70).

Em entrevista publicada no Portal Ultimato, ao ser questionado sobre o valor do evangelismo, René Padilla afirma:

Sem evangelização como comunicação oral do Evangelho não há prática da missão integral cristã. Esta abarca as dimensões da vida cristã: o ser, o fazer e o dizer. Ao mesmo tempo, a partir desta perspectiva, temos de afirmar que a evangelização não pode ser reduzida à comunicação oral do Evangelho, já que o testemunho cristão exige que o que os cristãos digam (ou proclamam) seja ratificado pelo que são e pelo que fazem. (PADILHA, 2014)

Nessa perspectiva, a salvação não está relacionada apenas à redenção pessoal, mas à de todo o mundo, quando novos céus e nova terra serão criados por Deus. A missão da igreja é ser um sinal histórico do reino de Deus, reino que tem como emblema o amor 
e a justiça. Cada igreja é, então, convidada a participar da missão de Deus, uma missão que tem alcance local, regional e mundial.

\section{CONSIDERAÇÕES FINAIS}

A discussão sobre a prioridade da missão da Igreja, e, em consequência, a responsabilidade social em relação aos pobres continua a ser objeto de discussão e investigação e longe está de ser encerrada. Diferentes pensamentos entre cristãos de denominações variadas nos levam a percorrer caminhos distintos. A maioria tem um contato com a sociedade em um âmbito assistencialista de ação social; outras igrejas preferem ficar somente com a pregação do evangelho; outras ainda optam por viver no âmbito da espiritualidade sem contato com o mundo; temos aquelas que pregam o imediatismo e o consumismo cristianizado e temos também aquelas que são extremamente sociais e políticas, deixando de lado a espiritualidade religiosa.

Nesse estudo, buscamos entender as diferentes respostas dos cristãos ao convite à misericórdia feito por Jesus. Para tanto, partimos da Bíblia, tanto no Antigo quanto no Novo Testamento e, em seguida, observamos qual o entendimento da igreja cristã católica e evangélica ao longo dos séculos. Vimos que grande parte dos cristãos prioriza o assistencialismo de ação social, outros defendem a prioridade da pregação do evangelho, enquanto outras ainda preferem isolar-se e evitar o contato com o mundo.

No entanto, a Bíblia nos ensina a evangelizar, a amar e a cuidar do próximo e esse cuidado deve se estender a todas a áreas da vida. Vimos que não se trata apenas do assistencialismo, de negligenciar o pobre ou de ações aleatórias, mas de um entendimento e de uma ação que é recomendada desde os primeiros livros da Bíblia, a fim de que o nome de Deus seja glorificado. Mesmo assim, sabemos que a restauração completa de toda a Criação só será efetivada com a volta de Cristo.

\section{REFERÊNCIAS}

BÍBLIA Sagrada. Trad. João Ferreira de Almeida. Rev. e atual. 2 ed. Barueri-SP: Sociedade Bíblica do Brasil, 2008. 
A. Sapsezian. Cadernos de O Estandarte n.11. Revista Teologia e Sociedade.

em:

http://www.teologiaesociedade.org.br/assets/caderno-

11 miolo.pdf. Acesso em: 28 jun. 2015.

BLAINEY, Geoffrey. Uma breve história do cristianismo. São Paulo: Fundamento Educacional, 2012.

BORGES, Letícia Oliveira. Teologia da Libertação e Teologia da Missão Integral: aspectos históricos, ênfases e diferenças. Vox Scripturae - Revista Teológica Internacional. São Bento do Sul/SC, vol. XXII, n. 2, jul-dez 2014, p. 63-73.

CARVALHO, Guilherme Vilela Ribeiro de. A missão integral na encruzilhada: reconsiderando a tensão no pensamento teológico de Lausanne. In.: RAMOS, Leonardo; CAMARGO, Marcel; AMORIM, Rodolfo (Org.). Fé cristã e cultura contemporânea. Viçosa, MG: Ultimato, 2009.

DEYOUNG, Kevin; GILBERT, Greg. Qual a missão da Igreja? entendendo a justiça social, a Shalom e a grande comissão. São José dos Campos, SP: Fiel, 2012.

DIDAQUÉ: o catecismo dos primeiros cristãos para as comunidades de hoje. São Paulo: Paulus. Disponível em: https://ibpan.com.br/images/stories/Downloads/

Estudos_Biblicos/DIDAQUE\%20\%20Catecismo\%20dos\%20Primeir os\%20Cristaos.pd. Acesso em: 09dez.2019.

FOUNTAIN, Jeff. Revolucionários e Antirrevolucionários: discipulando as nações na Idade Moderna. In: STIER, J; POOR, R; ORVIS, L. Venha o teu Reino: uma abordagem integrada para discipular as nações e cumprir a Grande Comissão. Almirante Tamandaré-PR: Jocum Brasil, 2008.

GOHEEN Michael W.; BARTHOLOMEW, Craig G. Introdução à cosmovisão cristã: vivendo na intersecção entre a visão bíblica e a contemporânea. São Paulo, Vida Nova. 2016.

. O drama das Escrituras. São Paulo: Vida Nova, 2004.

GOODE, G. Stephen. Amando a Deus e ao seu próximo: a influência da caridade e do ministério de misericórdia na sociedade. In: STIER, 
J; POOR, R; ORVIS, L. Venha o teu Reino: uma abordagem integrada para discipular as nações e cumprir a Grande Comissão. Almirante Tamandaré-PR: Jocum Brasil, 2008.

GRUDEN, Wayne. Teologia Sistemática. São Paulo: Vida Nova, 1999.

SÃO CLEMENTE ROMANO. Carta aos Coríntios. Biblioteca Patrística. Disponível em: https://sumateologica.files.wordpress.com/2010/02/clemente_roma no_cartas_aos_corintios. pdf. Acesso em: 04dez.2019.

KELLER, Timothy. Justiça generosa: a graça de Deus e a justiça social. São Paulo: Vida Nova, 2013.

Ministérios de misericórdia: o chamado para a estrada de Jericó. São Paulo: Vida Nova, 2016.

KUHN, Wagner. A prática da caridade e da beneficência social na igreja cristã. Faculty Publications. Paper 13. 2013. Disponível em: http://digitalcommons.andrews.edu/world-mission-pubs/13. Acesso em: 26 jul.2018.

LOPES, Augusto Nicodemus. A responsabilidade social da Igreja. Disponível em: http://www.seminariojmc.br/index.php/2018/01/04/o-ensino-decalvino-sobre-a-responsabilidade-social-da-igreja/. Acesso em: 02dez.2019.

LOPES, Fabrício Roger de Souza. Missão integral: uma perspectiva teológica da prática do evangelho na vida das igrejas. 2009. TCC (Graduação) - Universidade Metodista de São Paulo, São Bernardo do Campo, 2009.

MATOS, Alderi Souza de. A caminhada cristã na história: a Bíblia, a Igreja e a sociedade ontem e hoje. Viçosa-MG: Ultimato, 2005. OLIVEIRA, Antônio J. A contribuição de Calvino na administração de Genebra no século XVI. 2009. Dissertação (Mestrado em Ciência da Religião) - Universidade Mackenzie, São Paulo, 2009. 
PADILLA, René. 10 perguntas fundamentais sobre missão integral. Entrevista publicada no Portal Ultimato em 2014. Disponível em: https://www.ultimato.com.br/conteudo/10-perguntasfundamentais-sobre-missao-integral. Acesso: 04dez.2019.

SOUZA, Silas Luiz de. Pensamento sobre ação social no protestantismo brasileiro [PDF]. Ciências da religião $\begin{array}{lllll}\text { História e sociedade, } v . & 9, & \text { n. } & 1,\end{array}$ Disponível em: http://editorarevistas.mackenzie.br/index.php/cr/article/downloa d/3299/2948. URL: editorarevistas.mackenzie.br. Acesso em: 02dez.2019.

SILVA, Elizete da. Protestantismo e questões sociais. Sitientibus, Feira de Santana, n. 14, p. 129-142, 1996. Disponível em: http://www2.uefs.br/sitientibus/pdf/14/protestantismo_e_questoe s_sociais.pdf. Acesso em: 02dez.2019. 